\title{
Die Charismatiese Beweging in reformatoriese perspektief
}

\author{
AD Pont
}

\section{INLEIDENDE OPMERKINGS}

Die vraag wat beantwoord moet word, naamlik ' $n$ beoordeling van die charismatiese beweging èn die opvattings wat dit na vore bring vanuit die reformatoriese teologie, is nié so eenvoudig nie. Allereers seker al omdat die charismatiese beweging nie 'n enkelvoudige saak is nie en andersyds omdat die essensiële van die teologie in hierdie debat ter sprake is. Omdat in enige debat dit noodsaaklik is om met omlynde en duidelike begrippe te werk, om sodoende verwarring te voorkom, sal dit nodig wees om eers 'n paar sake kortliks te omskrywe.

\section{Die Charismatiese Beweging - wat is dit?}

Gewoonlik word gestel dat die Charismatiese Beweging in die vroeë sestigerjare sterk na vore gekom het as 'n beweging wat in die meeste groot Protestantse kerke na vore gekom het. Teen die einde van daardie dekade het dit veral onder due jeug van die VSA versprei in die gestalte van die "Jesus-revolusie" (Jooste, JH, Die Jesusrevolusie, Pretoria 1972, bl 2) en óók in die Roomse kerk ingang gevind. Die Charismatiese Beweging het ook die ekumeniese beweging beïnloed sodat dit beskrywe word as "a new era of the Spirit" wat dáármee tot stand sou gekom het (Beukes, MJ du P, Besondere Gawes van die Heilige Gees, artikel in Hervormde Teologiese Studies, Jrg 35, afl 3-4, bl 29-30 en ook De Wet, JI, Die garismatiese beweging - enkele inleidende opmerkings, artikel in Hervormde Teologiese Studies, Jrg 35, afl 3-4, bl 19-23). Ook in Suid-Afrika het die Charismatiese Beweging na vore gekom en beweeg sy invloed oor die kerklike grense en word kerklike en sektariese groeperinge deur dié beweging beroer.

Die Charismatiese Beweging het, volgens die beskikbare getuienis, voortgekom uit ' $n$ Amerikaanse beweging die Pentecostal Movement wat aan die einde van die vorige eeu in die VSA ontstaan het. Dié Pentecostal Movement is op sy beurt weer gevoed en rigting 
gegee deur verskillende strominge uit die sg Holiness Movement wat vanuit die Amerikaanse Metodiste Kerk na verskillende ànder Protestantse kerke in die VSA en ander Engelssprekende lande oorgespoel het. Dié Holiness Movement het, wat Suid-Afrika betref, 'n verteenwoordiger gevind in die persoon van dr Andrew Murray (vgl die anonieme artikel: Protestant Revivalism, Pentecostalism and the drift back to Rome, artikel in Present Truth, Fallbrook, California 1972, Sept-Okt, bl $22 \mathrm{vgl}$ ook Neve, J L, Churches and Sects of Christendom, Blair Nebraska 1952, p 360 v).

Die interessante in hierdie verband is dat al hierdie verskillende bewegings wat in meerdere of mindere mate ' $n$ bydrae gelewer het en lewer tot die bestaan èn voortbestaan van die Charismatiese Beweging, wat ons vandag bespreek, op die wortel van die Metodisme van John Wesley stoel. Dié Metodisme wat vanweë sy groot invloed, aangedui kan word as die "basis-teologie" of die grondliggende teologiese struktuur van die Engelstalige kerklike wêreld, staan op dié manier vader vir ' $n$ lang reeks van binne- èn buitekerklike bewegings èn groeperings. Die min of meer gemeenskaplike van ăl die bewegings, wat uiteindelik almal teruggevoer kan word na die figuur van Montanus in die tweede eeu, is die klem wat dáar gelê word op, wat mens sou kan noem, "die werk van die Heilige Gees".

As daar nou gevra word na die kenmerkende van die Charismatiese Beweging èn die dááraan voorafgaande groeperings en stromings dan kan, as enigermate vereenvoudig èn veralgemeen mag word, die volgende genoem word.

Allereers is daar ' $n$ byna standaard-beswaar téén die gevestigde kerke, naamlik dat dáár geen of baie min aandag aan die Heilige Gees en sy werk gegee word nie; dat die kerke en veral hulle godsdiensoefeninge koud, "leweloos" èn formalisties-star is; dat die lidmaat en sy ervaring van sy geloof of van die Heilige Gees se werk nié aandag kry nie; dat alles in die kerk in die hande geplaas word van die predikant en die ingestelde ampte en dat die kerk sodoende géén ander doel het as om die kerk voort te bou nie.

Daartéénoor beklemtoon die Charismatiese Beweging dat sy lede met die Heilige Gees gedoop is (na aanleiding van Mark 1:8; Luk 3:16; Matt 3:11; Joh 1:33, Hand 1:5, 11:16; I Kor 12:13) en vandaar al die charismata of gawes-genadegawes waarvan die Nuwe Testament praat, ontvang het. Dit wil sê hulle spreek in tale en genees siekes en daaruit kan gesien word dat hulle ware gelowiges is. 
Verder word die gedagte van 'n georganiseerde geloofsgemeenskap soos die kerk, nie baie hoog geskat nie. In die plek dáárvan word eerder van 'n vergadering van gelowiges gepraat wat charismatiese leiers het en nie ingestelde ampte nie. Ook die godsdiensoefening word spontaan gestruktureer met 'n groter deelname van die lidmate deur middel van individuele gebede, getuienisse en opgewekte sang en musiek.

'n Persoonlike asketisme gekoppel aan die verwagting van die spoedige terugkeer van ons Heer, Jesus Christus, speel in hierdie beweging ook 'n belangrike rol.

Dan is dit ook 'n algemene verskynsel dat die persoonlike leiding van die Heilige Gees, 'n direkte kennis van God en sy wil deur middel van die Gees en die beklemtoning van die waarde van die persoonlike ervarings hoër geag word as die Skrif. Terselfdertyd word die Skrifwaarhede wat sorgvuldig deur die kerk deur die eeue omlyn en vasgestel is, as grotendeels minderwaardig in vergelyking met die direkte persoonlike ervaring en belewing van die besit van die Heilige Gees, aangedui. Die leerstellings van die kerk sou deel wees van die "dooie formalisme" van die kerk wat nié meer aanvaarbaar is nie.

Dit alles dui op 'n totaal ánder lewens- en ervaringswêreld, selfs 'n totaal ànder verstáán van God en sy Woord èn die verhouding God en mens as wat in die reformatoriese teologie èn kerke na vore kom. Dit is selfs ' $n$ vraag of daar tussen die reformatoriese teologie en die Charismatiese Beweging 'n wesenlike gespreksmoontlikheid bestaan. Dit juis omdat fundamentele verskille bestaan oor die verstaan van die Woord van God en die Heilige Skrif, die verhouding van Woord en Heilige Gees, en dan verder oor sulke grondliggende sake soos die mens, die sonde, die verlossing van die mens uit die sonde, die genade van God èn die hele struktuur van die verhouding God en mens.

As daar vanuit die reformatoriese teologie na die Charismatiese Beweging gekyk word, dan is daar 'n paar aangeleenthede wat uitgelig kan word.

\section{DIE CHARISMATA EN DIE ORDE VAN DIE KERK}

Die gemeenskap met Christus èn met die Heilige Gees skep 'n nuwe gemeenskap. Maar dit is nie 'n ordelose gemeenskap nie. Inteendeel, in hierdie nuwe gemeenskap gee Christus self, deur die Heilige 
Gees, 'n vaste, blywende orde, naamlik die sigbare, georganiseerde kerk.

In dié nuwe gemeenskap skenk God bepaalde charismata (= genadegawes) en dié gawes word aan 'n bepaalde persoon of aan meer gegee tot opbouing en vertroosting (Rom 1:11). Die aard van dié gawes van die Gees word ook soms ànders aangedui as ergon (= werk Ef 4:12), as oeconomia (= beheer I Kor 9:17) en leiturgia (= dienswerk, II Kor 9:12). Hieruit word dit duidelik dat dit om gawes gaan wat Christus deur sy Gees aan die gemeente gee. Hieronder word verstaan àlles wat lering en vermaning, asook tot die onderlinge diensbetoon, of die doeltreffende bestuur en regering van die gemeente kan dien (Smit, CJ, 1984. God se orde vir sy kerk, Pretoria NG Kerkboekhandel, bl 31). Dit is opmerklik dat die meeste NuweTestamentici dit beklemtoon dat die charismata gegee word om die gemeentes te bou en dat die uitlewing van die charismata nié die orde van die gemeente en sy samekoms mag versteur nie (I Kor 12:12-30). Juis die menslike willekeurigheid wat gepaard gaan met die sg charismatiese verskynsels in die Charismatiese Beweging laat die vraag ontstaan of dit nie juis in botsing is met die orde wat die Gees óók aan die gemeente gee nie, (vgl I Kor 14 waar Paulus juis die charismatiese ongebondenheid en willekeur afwys). Die poging in die Charismatiese Beweging om die charismata te láát herleef en om so die indruk te probeer skep dat alleen dit regte kerklike orde is waar 'n Nuwe-Testamentiese voorbeeld herhaal word, hang saam met 'n opvatting dat géén kerklike orde uit die Nuwe Testament afgelei kán word nie en dat alles dáár charismaties was. Daarmee word vergeet dat die diakonia óók charisma is, dat die vaste ampte èn die reëlmatige orde, die opbou van die kerk, die orde en gestalte van die kerkregering met die doel om die liggaam van Christus na sý eis uit te bou 'n duidelike Skriftuurlike opdrag is. Dáárom bely die kerk in die Nederlandse Geloofsbelydenis, art 30:

"Ons glo dat hierdie ware kerk ooreenkomstig die geestelike bestuurswyse wat ons Here ons in sy Woord geleer het, geregeer moet word."

\section{DIE CHARISMATA EN DIE LEER VAN SONDE EN GENADE}

In die Charismatiese Beweging is die sentrale boodskap dat die doop met die Heilige Gees of die ontvang van die Heilige Gees, 'n gebeure is wat plaasvind nà die kinderdoop, nà 'n bekering en nà 
die ontvang van die geloof. Of, om dit effens anders te stel: die Charismatiese Beweging lê 'n besondere klem op die doop ín of mèt die Heilige Gees wat dan as ' $n$ twééde ervaring in die gelowige se verhouding tot God gesien moet word. Hierdie tweede ervaring is volgens sommige 'n definitiewe èn éénmalige vervulling met die Heilige Gees. Volgens ànder is dit slegs 'n eerste vervulling wat telkens deur nuwe vervullings met die Heilige Gees gevolg kan word. Dit is met ander woorde ' $n$ frekwentatiewe gebeure. Elkeen wat nie in die Heilige Gees gedoop is nie, is volgens die Charismatiese Beweging nié 'n ware Christen of 'n gelowige nie.

Laat ons allereers sê dat die Bybels-reformatoriese teologie ons leer dat die natuurlike mens ' $n$ volkome sondaar is en dat géén mens daarvan uitgesluit is nie (Rom 3:23). Dié sondaar kan géén enkele bydrae tot sy verlossing uit die sonde lewer nie. Uit louter goedheid stuur God egter verkondigers van die evangelie dat almal wat in Jesus Christus glo, nié verlore sal gaan nie, maar die ewige lewe sal hê (Joh 3:16 en 1 Joh 4:9).

Deur die diens van hierdie verkondigers van die evangelie, ontvang mense die geloof, die verlossing uit die sonde, die regverdigmaking om Jesus Christus ontwil (Rom 3:21-26). Geregverdig deur die geloof in Jesus Christus wat die skuld en straf van die sonde op Hóm geneem het, is die gelowige 'n volkome verloste (Kol 1:20-22 en 2:10; vgl Heb 10:14). Verbonde aan Jesus Christus vanweë die genadegawe van die geloof, is die gelowige "vir die sonde dood" (Rom 6:11). Sáám met die geloof, sáám met die regverdigmaking ontvang die verloste óók die Heilige Gees (Rom 5:1-5).

Dit is duidelik dat die genadegawe van die geloof, die regverdigverklaring van die sondaar, die volkome verlossing uit die sonde ' $n$ gawe van God is wat van buite ons na ons toe kom. Dit is suiwer genade om dié genade te ontvang. Daarbý, sáám daarmee ontvang die gelowige die Heilige Gees (Ef 1:12-14). In die Charismatiese Beweging word die indruk geskep dat die genadegawe van die geloof en die regverdigverklaring van die sondaar deur God nog nie beteken dat dáárdie gelowige die Heilige Gees ontvang het of sal ontvang nie. Dit is 'n kapitale dwaling.

Die tweede saak wat die Charismatiese Beweging stel, naamlik dat die ervaring van die doop deur die Heilige Gees 'n groter of belangriker gebeure in die lewe van die gelowige sou wees as die reverdigverklaring van die sondaar, is Skriftuurlik nié houdbaar nie. Juis in hierdie saak maak die Charismatiese Beweging 'n skeiding tussen 
die geloof in Jesus Christus en die ontvang van die Heilige Gees en word die indruk gewek dat die geloof in Christus slegs 'n voorstadium is van die ware en egte wat eers beleef word met die sg "uitstorting" van die Heilige Gees (vgl egter I Kor 1:30, Kol 2:9-10).

Dit hang saam, in laaste instansie, met die Charismatiese Beweging se opvatting van sonde èn genade waar hulle erflik belas is vanweë die Armenianisme van die Metodisme. Vanweë hierdie ontsporing word die objektiewe waarheid van die Woord van God opsygeskuif om plek te maak vir die religieuse ervaring van die mens. Dáárom is die kinderdoop, die kategetiese onderrig van die kind in ouerhuis en kerk, die gewone lees van die Bybel, die huisgodsdiens van die Christelike huisgesin en die normale kerkgang met die sentrale moment van die Woordverkondiging, vir die Charismatiese Beweging nooit voldoende nie. Dit sou dan té formeel, te koud, te leweloos wees, want dáár vind geen spektakulêre "geesteservarings" plaas nie. Immers die subjektiewe menslike ervaring het hier voorrang gekry bo die objektiewe waarheid van die evangelie. Dit dui op sy beurt weer daarop dat in die Charismatiese Beweging daar ' $n$ ànder opvatting bestaan oor die samehang van die Woord van God en God, die Heilige Gees.

\section{WOORD EN GEES}

Vanuit die reformatoriese teologie is juis hiérdie beklemtoning van die subjektiewe menslike ervaring 'n simptoom daarvan dat, net soos Thomas Müntzer in die 16de eeu, die Woord van God losgemaak is van God, die Heilige Gees. Dáárom het hy méér staatgemaak op direkte openbarings èn ervarings wat hy aan die Heilige Gees toegeskryf het, as op die eenvoudige Woord.

In die voetspoor van die Skrif self (Joh 14:25, Joh 16:13-14) het die reformatoriese teologie vasgehou aan die kardinale beginsel dat die Heilige Gees juis gekom het om die Skrif uit te lê, die werk van Jesus Christus toe te pas en om Christus te verheerlik. Met klem het die reformatoriese teologie nog altyd vasgehou aan die éénmaligheid èn voltooidheid van God se openbaring in Jesus Christus. Daarom glo ons, saam met die NGB, art 7:

"... dat hierdie heilige Skrif die wil van God volkome bevat en dat alles wat die mens vir sy saligheid moet glo, dáárin voldoende geleer word .... En aangesien dit verbode is om iets by 
dié Woord van God by te voeg of daarvan weg te laat (Deut 12:32), blyk dit duidelik dat die leer daarvan heeltemal volmaak en in alle opsigte volkome is."

In die Barmen Thesen, uit die dertigerjare van ons eeu, word dit as volg geformuleer:

"Jesus Christus, soos $\mathrm{Hy}$ in die Heilige Skrif aan ons betuig word, is die enige Woord van God wat ons moet hoor en in lewe en sterwe moet vertrou en gehoorsaam.

Ons verwerp die dwaalleer dat die kerk as bron van sy prediking behalwe en langs hierdie enige Woord van God, ook nog ànder gebeurtenisse, magte, figure en waarhede as openbaring van God sou kan en moet erken."

Waar die Woord en die Gees van mekaar losgemaak word, kom daar allerlei merkwaardighede na vore soos Thomas Müntzer en Jan van Leiden so duidelik in die 16 de eeu gedemonstreer het.

Waar Woord en Gees van mekaar losgemaak word, kom daar steeds allerlei beskuldigings téén die kerk na vore. Maar waar die verbinding Gees en Woord gehandhaaf word, is daar altyd die moontlikheid van die hervorming van die kerk na die eis van die Woord. Immers in die lewe van die kerk gaan dit om die geloof in en gehoorsaamheid aan die Woord van God in die wete dat die Heilige Gees dáár is waar die Woord reg verkondig word.

\section{AFSLUITENDE OPMERKINGS}

As die Charismatiese Beweging en sommige van sy opvattings en dogmata van naderby besien word, dan word dit duidelik dat hier eintlik niks nuuts na vore kom nie. In baie gevalle is dit nie veel meer as stokou dwalings nie. Die enigste verskil is dat hierdie dwalings netjies verpak, aantreklik aangebied en met moderne verkoopstegnieke bemark word. Dit is ook opvallend dat die Charismatiese Beweging in sy verskillende fasette maksimale propaganda put uit die feit dat mense wat in die kalklig is, tot dié beweging toegetree het. Dit is opvallend hoe bedrywig mense in hierdie beweging is en hoe afhanklik alles van mense is. Miskien kan dit versoberend werk om weer ' $n$ keer te luister na 'n opmerking van Martin Luther wat in één van sy preke gesê het: 
"Ek het maar net die Woord van God geleer, gepreek en daaroor geskryf. Méér as dit het ek nie gedoen nie. Die Woord sèlf het, terwyl ek geslaap het, terwyl ek Wittenbergse bier saam met my vriende, Philippus Melanchton en Nicolaas Amsdorf gedrink het, die pousdom só verswak dat geen vors of keiser ooit vantevore dit soveel skade aangedoen het nie. Ek het niks gedoen nie, die Woord van God het ălles gedoen èn uitgevoer."

Die Charismatiese Beweging met sy beklemtoning van die noodsaaklikheid dat ' $n$ mens met die Gees vervul moet wees en neersien op die gewone gelowiges wat "maar net gered is", trek net soos die Gnostiek van die tweede eeu 'n verdelingslyn in die kerke en gee voor om 'n soort hoëre, beter, suiwerder geloof uit te dra en te bewerkstellig. Dáărmee loop hulle denke téén die sentrale momente van die evangelie van Jesus Christus, die gekruisigde en opgestane Heer.

Hoewel die Charismatiese Beweging miskien wèl tekortkomings in die lewe van die kerk ontbloot in dié sin dat baie lidmate hulle geloof nie uitleef nie, in dié sin dat die kerke dikwels die gemeenskap van die gelowiges nie beleef nie, is die dogmatiese dwalings van die Charismatiese Beweging egter van so 'n aard dat daar 'n groot kloof tussen die kerk en die beweging bestaan. Die enigsins hooghartige selftevredenheid waarmee die Charismatiese Beweging dié kloof bejeën, maak dit moeilik om 'n sinvolle gesprek vanuit die kerk met dié beweging te voer. 